\begin{tabular}{cc} 
Türk Coğrafya Dergisi & Turkish Geographical Review \\
Basılı ISSN 1302-5856 & ww.tcd.org.tr \\
\hline $\mathbf{1 9 4 1 *}$ & Elektronik ISSN 1308-9773
\end{tabular}

\title{
Filyos Çayı Deltasında (Karadeniz) kıyı çizgisi değişiklikleri ve yakın geleceğe yönelik göstergeler ${ }^{1}$
}

\section{Shoreline change in the Filyos River Delta on the Black Sea and indications for near future ${ }^{2}$}

\author{
Hüseyin Turoğlu a* (D) Abdulkadir Duran ${ }^{b}$ \\ ${ }^{a}$ Istanbul Üniversitesi, Edebiyat Fakültesi, Coğrafya Bölümü, ístanbul, Türkiye. \\ ${ }^{b}$ Istanbul Üniversitesi, Sosyal Bilimler Enstitüsü, Istanbul, Türkiye.
}

ORCID: H.T. 0000-0003-0173-6995; A.D. 0000-0001-6267-8798

\section{BILGI / INFO}

Geliş/Received: 31.10 .2021

Kabul/Accepted: 22.11.2021

\section{Anahtar Kelimeler:}

Filyos Çayı Deltası

Jeomorfoloji

Kıyı çizgisi değişimi

CBS \& UZAL

Keywords:

Filyos River Delta

Geomorphology

Shoreline change

GIS \& RS

*Sorumlu yazar/Corresponding author: (H. Turoğlu) turogluh@istanbul.edu.tr

DOI: $10.17211 /$ tcd.1016928

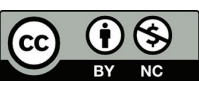

\section{Attf/Citation}

Turoğlu, H., \& Duran, A. (2021). Filyos Çay Deltasında (Karadeniz) kıyı çizgisi değişiklikleri ve yakın geleceğe yönelik göstergeler. Türk Coğrafya Dergisi, (78), 61-74. https://doi.org/10.17211/tcd.1016928

\begin{abstract}
ÖZ / ABSTRACT
Hisarönü (Filyos) Balıkçı Barınağı ve Filyos Limanı inşaatları sonrasında, Filyos Çayı Deltası kıyılarında; kıyı çizgisi, plaj ve artkıyı alanında zamana bağlı değişiklikler dikkat çekici olmaya başlamıştır. Bu çalışmada; Filyos Çayı Deltası kıyılarında kıyı çizgisinin zamana bağlı değişimi analiz edilerek, bu değişimlerinin miktarları, hızı, alan ve lokasyon özelliklerinin belirlenmesi amaçlanmıştır. Araştrrma, Coğrafi Bilgi Sistemleri ve Uzaktan Algılama teknolojileri ile gerçekleştirilen analiz yöntemlerine dayalı olarak gerçekleştirilmiştir. Sonuçlar arazi çalışmaları ile test edilmiştir. Veri kaynağı olarak 1984-2020 yıllarına ait 5 er yıllık dönemler için Landsat uydu görüntüleri tercih edilmiştir. Kıyı çizgilerinin belirlenmesi için "Normalized Difference Water Index (NDWI)" yöntemi, kıyı çizgilerinin değişimi, kıyı erozyonu ve birikimi analizi için ise "Digital Shoreline Analysis System (DSAS)" kullanılmıştır. Plaj ve artkıyıdaki alansal değişimleri belirlemek için ArcGıs 10.5 yazılımdaki "Image Analyst" uzantısında bulunan "Difference" aracından yararlanılmıştır. Analiz sonuçları, Hisarönü Balıkçı Limanı'nın doğu kıyısında 36 yılda 51.70 - 259.42 metre arasında kıyı çizgisi ilerlemesinin ve kum birikiminin gerçekleştiğini göstermektedir. Diğer taraftan, Filyos Limanı proje sahasında, kıyı çizgisinin -229.49 ile -366.32 metre arasında gerilediği tespit edilmiştir. Analiz sonuçları kıyı çizgisi değişimlerinin, kıyı yapılarının inşaatından sonra belirgin olarak hızlandığını göstermektedir. Kıyı çizgisi ilerlemeleri ve oluşan kum birikimlerinin gelişim hızları da dikkate alındığında, yakın gelecekte; Hisarönü Balıkçı Barınağının girişinin kapanacağı, Hisarönü Balıkçı Barınağının doğusundaki Tios antik limanının kum birikimi altında kalacağı öngörülmektedir.
\end{abstract}

After the construction of Hisarönü (Filyos) Fishing Harbour and Filyos Port, remarkable changes in the shoreline, beach and backshore area were observed on the Filyos River Delta. In this study, the changes of the shoreline on the Filyos River Delta were analyzed, and the degree, speed, area and location characteristics of these changes were investigated. The research was carried out based on Geographic Information Systems (GIS) and Remote Sensing (RS) technologies. The results were tested by field studies. As the data source, Landsat satellite images for 5-year periods from 1984 to 2020 were preferred. Normalized Difference Water Index (NDWI) was used for determination of the shorelines, and the Digital Shoreline Analysis System (DSAS) was used for analysis of the change in the shoreline, erosion and sand accumulation. The "Difference" tool in the "Image Analyst" extension of ArcGIS 10.5 software was used to determine the spatial changes in the beach and backshore. The results of the analysis indicate that shoreline progression and sand accumulation of between 51.70 - 259.42 meters have occurred during 36 years on the eastern shore of Hisarönü Fishing Harbour. On the other hand, in the area of Filyos Port, it was determined that the shoreline had retreated between -229.49 and -366.32 meters. These results show that the shoreline changes accelerated significantly after the construction of the newly-built coastal structures. Considering the shoreline progression and the development rate of the sand accumulation, it is predicted that the entrance of Hisarönü Fishing Harbour will be closed in a short time due to the sand, and the ancient Tios Port east of the Hisarönü Fishing Harbour will be submerged under sand fill.

\footnotetext{
1 Bu çalışmada “Gelik Deresi (Zonguldak) - Bartın Çayı (Bartın) Arasının Uygulamalı Kıyı Jeomorfolojisi Etüdü” başlıklı Yüksek Lisans tez çalışmasının sayısal veri tabanından faydalanılmıştır.

2 In this study, the digital database of the master's thesis titled "Applied Coastal Geomorphology Study Between Gelik River (Zonguldak) - Bartin River (Bartin)" was used.
} 
Extended Abstract Introduction

A "shore" is a landform with particular characteristics. This geomorphological unit, which defines an area, separates the aquatic and terrestrial environment with clear boundaries. The "shoreline" represents the boundary where the water comes into contact with the land. This line is not stable and may change along the shore; according to natural or anthropogenic processes. The shore of the Filyos River Delta $\left(41^{\circ} 3300^{\prime \prime}-41^{\circ} 3542^{\prime \prime} \mathrm{N}\right.$ and $\left.32^{\circ} 0018^{\prime \prime}-32^{\circ} 0655^{\prime \prime} \mathrm{E}\right)$ is one where the shoreline typically changes. This occurs in relation to the interplay between morphodynamic processes and shore structures (Figure 1). It was observed that the rate of change of the shoreline gradually increased after the construction of the port and fishing harbour in the delta. This study aims to analyse the speed and trend of the changes in the shoreline boundary and area characteristics of the Filyos River Delta and to make predictions based on the results using Geographic Information Systems (GIS) and Remote Sensing (RS) technologies.

\section{Method and Data}

GIS and RS technologies were the main research methods used in this study. Landsat satellite images were preferred as the historical data source. From 1984 to 2020, with an average of five-year periods, eight differently dated satellite images were obtained from the USGS website (Table 1). The Normalized Difference Water Index (NDWI) was used as the shoreline determination method (Figure 2). The areal changes of the shore were calculated from the shoreline changes. The Digital Shoreline Analysis System (DSAS) application was applied to detect the change in the shoreline occurring under the influence of erosion and deposition on the delta shores (Figure 3). The DSAS method is an application that can be used as a plug-in for the ArcGIS software. The DSAS analysis gave effective results in the determination of erosion and accumulation on the delta's shores at short- and long-time intervals. The Shoreline Change Envelope (SCE), Net Shoreline Movement (NSM), End Point Rate (EPR), and Linear Regression Rate (LRR) statistics were calculated by DSAS analysis. Landsat 4-5 and Landsat 7 satellite images dated at 16/07/1984 and $12 / 08 / 2020$ were preferred to determine the changes in the beach and backshore areas. Landsat images were classified with the 'Difference' tool in the 'Image Analyst' menu of ArcGIS 10.5 software. In the classification, based on the spectral reflection properties of the shore's sand, the pixel values of the image were taken into account and the differentiation of the shore areas was determined.

\section{Results and Predictions}

In the shoreline change analyses performed with the DSAS method for the 5-year periods between 1984-2020, it was calculated that the maximum amount of advance on the shoreline in the Filyos River Delta was in the 1995-2000 period. This progress was $120.37 \mathrm{~m}$ according to the NSM statistics, and $24.42 \mathrm{~m} / \mathrm{y}$ according to EPR statistics (Table 2, Figures 4,5 ). It was calculated that the greatest amount of regression on the shoreline occurred in the 2015-2020 period. This regression, calculated by DSAS analysis, is observed to be $-156.73 \mathrm{~m}$ according to NSM, and $-31.11 \mathrm{~m} / \mathrm{y}$ according to EPR (Table 2, Figures 4). That the time of the regression of the shoreline on these shores coincides with the start of the construction of Filyos Port is extremely significant (Table 2).
In the shoreline analyses, erosion and shoreline regression ranging from $-229.49 \mathrm{~m}$ to $-366.32 \mathrm{~m}$ was calculated for the 36 -year period of $1984-2020$ (Figure 4). It was calculated that $-156 \mathrm{~m}$ to $-102.68 \mathrm{~m}$ of this regression occurred only in 2015-2020 (Figure 4, Table 3). It is therefore understood that this remarkable change occurred anthropogenically and simultaneously with the port construction works, especially in the Filyos Port Project area.

Shoreline progression and therefore areal growth on the shore area by sand accumulation took place on the eastern shores of Hisarönü Fishing Harbour at distances varying between $51.70 \mathrm{~m}$ and $259.42 \mathrm{~m}$ during 1984-2020 (Figure 4). The shoreline progression on the same shores continued with a displacement of $14.40-89.40 \mathrm{~m}$ in the growth of the sand accumulation area on the shore in the 2015-2020 period (Figure 4). Based on the 36-year coastline change trend, it is noteworthy that the steady change in the amount of shoreline advance (NSM) and speed (EPR) coincided with the construction of the Hisarönü Fishing Harbour.

The rapid growth of sand accumulation in front of the eastern breakwater of Hisarönü Fishing Harbour has reduced the distance of the harbour entrance from $85 \mathrm{~m}$ to $26 \mathrm{~m}$, especially in the last 10 years (Figure 7). If the annual rate of progress of $\pm 5 \mathrm{~m}$ continues in this way, it is foreseen that the entrance of Hisarönü Fishing Harbour is at high risk of being closed up soon.

A foreshore and backshore area-change map was created using Landsat 4-5 (TM) Band 3 dated July 16, 1984, and Landsat $7(E T M+)$ Band 3 data sources dated August 12, 2020, using the ArcGIS 10.5 "Image Analyst" extension "Difference" tool (Figure 8). This analysis was carried out by comparing the image pixels one-by-one and defining the differences and similarities between them.

The analysis results show that the beach and shore dune area, which was $2.11 \mathrm{~km} 2$ on the Landsat 4-5 (TM) image dated July 16,1984 , decreased by $18.48 \%$ to $1.72 \mathrm{~km} 2$ in the Landsat 7 $(\mathrm{ETM}+)$ image dated August 12, 2020. (Figure 8). The dark red area (shore erosion area) to the west of Filyos Port and inside the port (Figure 3 ) is anthropogenic change due to excavation for the port construction project and represents a significant portion of the $18.48 \%$ reduction.

The harbour and harbour structures of the ancient city of Tios, which is an archaeological heritage site and is partly submerged today, face a high risk of being submerged under the accumulation of sand because of the shoreline progression on the eastern shore of Hisarönü Fishing Harbour. Between 2010 and 2021, it is observed that the shoreline progressed regularly, the shore area expanded, and the ancient harbour was covered by more sand deposits from year to year (Figure 10). The annual average rate of the shoreline progression, reaching $1.81 \mathrm{~m} /$ year from 2010 to 2014, $4.65 \mathrm{~m} /$ year in the period of 2014-2018, and $5.56 \mathrm{~m} /$ year in the period of 2018-2021, indicates the extent of the hazard (Table 4). If this annual progression trend of the shoreline continues, it is foreseen that the underwater ancient harbour structures will soon be completely covered and buried by sand. 


\section{Giriş}

Yeryüzü şekillerinin oluşumu ve gelişiminde endojenik etkenler ana yapısal özelliklerin ortaya çıkmasında rol alırken, eksojenik etkenler ve insan da aşındırma, taşıma, biriktirme faaliyetleri ile bu gelişimi şekillendirir. Bu yaklaşım kapsamında; kıyının su ortamı tarafindaki kıyı kenar çizgisi ile kara tarafindaki kıyı kenar çizgisi, kıyı tipi, boyutları, esas itibarıyla kıyı jeomorfolojisi zaman içinde değişim gösterir (Stanica \& Ungureanu, 2010; Turoğlu, 2017; Turoğlu, 2019). Kıyı çizgisi de en fazla değişimin gerçekleştiği kıyı elemanlarından biridir. Özellikle kıyıdaki insan müdahaleleri (liman inşaat, kazı-dolgu ve diğer projeler) başta kıyı çizgisi olmak üzere kıyının jeomorfolojisi üzerinde çok önemli değişikliklere neden olur (Erol, 1997; Reed, 2002; Turoğlu, vd. 2004; Turoğlu, 2005; UNEP, 2006; Davidson-Arnot, 2010; Turoğlu, 2019; Vélez-Castaño, vd. 2021).

Filyos Çayı Deltası kıyıları, morfodinamik süreçler ve kıyı yapıları ilişkisi içinde meydana gelen kıyı çizgisi değişiminin tipik olarak gerçekleştiği kıyılardan biridir. Kıyı çizgisi değişim hızının liman ve balıkçı barınağı inşaatları sonrasında giderek arttı̆ı görülmektedir. Bu çalışmada; Coğrafi Bilgi Sistemleri (CBS) ve Uzaktan Algılama (UZAL) teknolojileri kulanılarak, Filyos Çayı Delta kıyısı sınır ve alan özelliklerinde meydana gelen değişimlerin hız ve eğilim analizlerinin gerçekleştirilmesi, analiz sonuçlarına dayandırılan öngörülerin yapılması hedeflenmiştir.
Çalışma sahası kabaca $41^{\circ} 3300^{\prime \prime}-41^{\circ} 3542^{\prime \prime}$ kuzey paralelleri ile $32^{\circ} 0018^{\prime \prime}-32^{\circ} 0655^{\prime \prime}$ doğu meridyenleri arasında kalan kıyı alanıdır. Bu kıyı içinde Filyos Çayı'nın mansabı, onun 1,5 km doğusunda Filyos Limanı ve 2,7 km batısında Hisarönü (Limanı) Balıkçı Barınağı yer almaktadır (Şekil 1).

Filyos Vadisi Projesi kapsamında inşa edilen ve yapımına 2014 yılında başlanan Filyos Limanı (Şekil 1), konteyner, dökme, kath-sıvı ve cevher yükü olmak üzere 25 milyon ton kapasiteye sahip olarak uluslararası planlanmıştır. Ekonomik açıdan farklı boyutlarıyla önem arz eden Filyos limanının doğal süreçler ve kaynaklar üzerindeki etkileri de tartışmalıdır. Liman inşaat; 2,5 km uzunluğundaki kıyıda, 1,0 km denize dolgu yapılarak, inşaat için yaklaşık 2,5 km2 lik bir alan kullanılmıştır (Avcı \& Avcı, 2001; Çetinkaya, 2012; Atş \& Çelikoğlu, 2019; Filyosvadi, 2021). Dikdörtgen formundaki liman inşaat ile sadece önkıyı ve artkıyıda yapılan kazılarla değil, aynı zamanda denize yapılan dalgakıran dolguları nedeni ile kıyının tüm bölümlerinde derinlik, eğim ve alansal özellikler üzerinde önemli değişiklikler gerçekleştirilmiştir. Çalışma sahasındaki diğer kıyı yapısı Hisarönü Balıkçı Barınağı (HBB) dir (Şekil 1). Bu kıyı yapısı bölgede, 2000 li yıllardan önce inşaatı tamamlanan 5 Balıkçı Barınağı inşaatından biri olup, Ulaştırma Bakanlığı DLH İnşaatı Genel Müdürlüğü’nce ihalesi yapılan Tarım Sektörü 94-A040370 proje numaralı altyapı yatırımıdır (HBB, 2006).

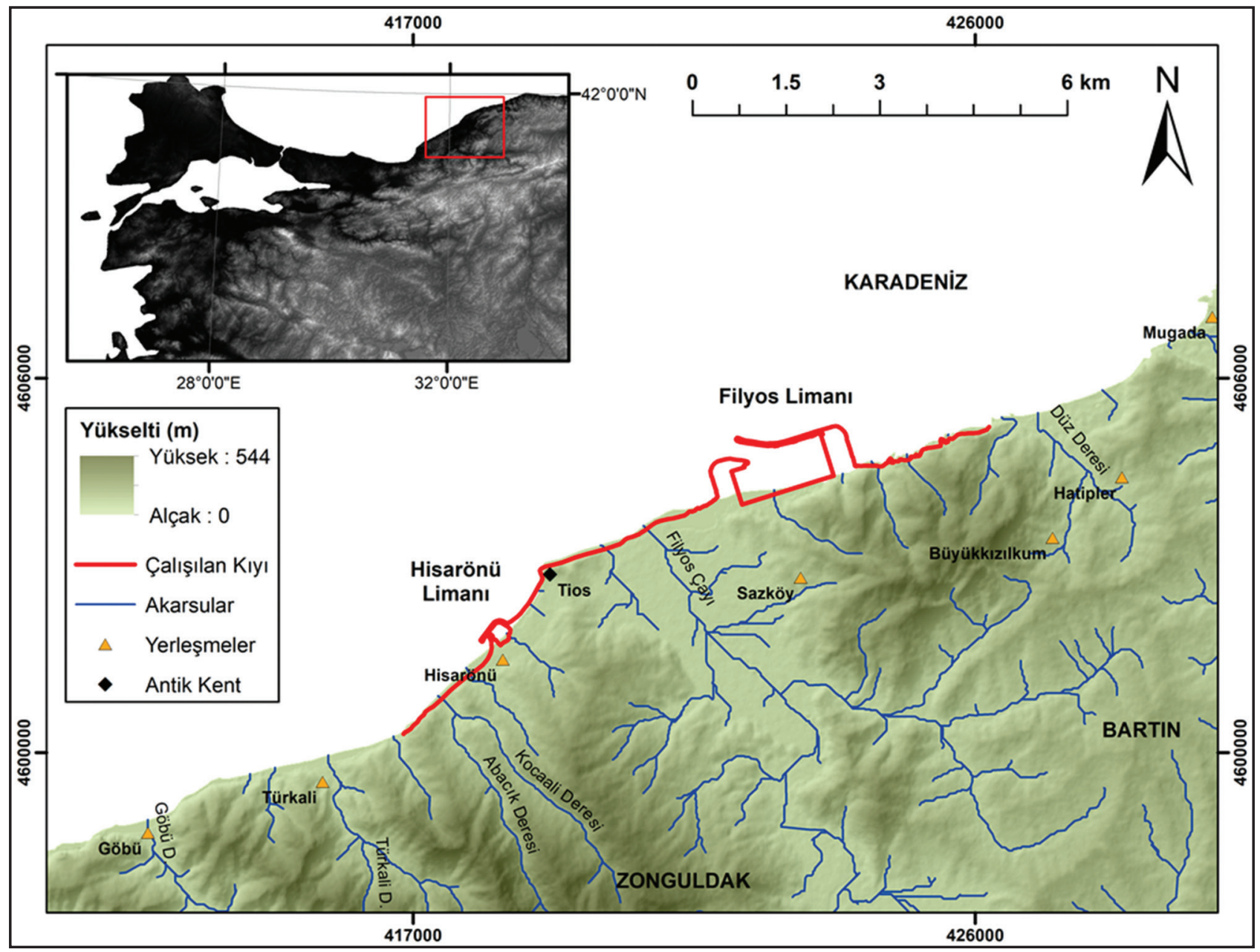

Şekil 1. Çalışma sahasına ait lokasyon haritası.

Figure 1. Location map of the study area. 


\section{Materyal ve Yöntem}

Delta kıyısı sınır ve alan özelliklerinde meydana gelen değişimlerin belirlenmesi, izlenmesi çalışmalarında Coğrafi Bilgi Sistemleri (CBS) ve Uzaktan Algılama (UZAL) teknolojileri sıkIıkla kullanılmaktadır (Thao, vd. 2013; Wang, vd. 2013; Liu, vd. 2017; Mahamud \& Takewaka, 2018; Fan, vd. 2019; Wang, 2019; Liu, vd. 2020; Vélez-Castaño, vd. 2021). Bu çalışmada da temel araştırma yöntemi olarak CBS ve UZAL teknolojileri kullanılmıştır. Araştırma materyallerinden geçmiş tarihli veri kaynağı olarak Landsat uydu görüntüleri tercih edilmiştir. 1984 yılından 2020 yılına kadar, ortalama beşer yıllık dönemlere ait olmak üzere, USGS web sitesinden, toplam sekiz farklı tarihli uydu görüntüsü temin edilmiştir (USGS, 2021). Uydu görüntülerinin seçiminde ayrıca bulutluluk oranının düşük olmasına ve mevsimsel farklılıkların oluşturabileceği dezavantajların önüne geçmek için yaz aylarına ait ve tarihlerin birbirine yakın olmasına özen gösterilmiştir (Tablo 1). Analizler için kullanılan uydu görüntülerinin yersel çözünürlükleri $30 \mathrm{~m}$ dir (Tablo1). 30 m yersel çözünürlük; bu çalışmanın sonuçları açısından bir handikap olarak görülebilir. Ancak bu çalışmanın önceliği; yüksek hassasiyetli sonuçlardan çok, yöntem ve çıkt kazanımları olarak görülmektedir. Yüksek yersel çözünürlüklü verilerin kullanılması ile bu çalışmanın bulguları doğrultusunda, çok daha hassas sonuçlara ulaşılması mümkündür.

Bu çalışmada kıyı çizgisi belirleme yöntemi olarak; Normalleştirilmiş Fark Su İndeksi (Normalized Difference Water Index-NDWI) yöntemi tercih edimiştir. McFeeters (1996) tarafindan ortaya koyulan NDWI yöntemi, su ve su dışı ortamların sınıflandırılması çalışmalarında sıklıkla kullanılan su indekslerinden biridir (McFeeters, 1996; Xu, 2006; Liu, vd. 2017; Mitra, vd. 2017). Su yüzeyleri; yeşil bantta radyasyonu yansıttr ve NIR bandında absorbe eder (Mitra, vd. 2017). Karasal bitki örtüsü ve toprak yüzeyler ise NIR bandında yeşil banttan daha yüksek yansımaya sahiptirler. Su ve su olmayan yüzeyin farklı yansıtma özelliği esas alarak yapılan sınıflama yöntemi olan NDWI yönteminde aşağıdaki formül (1) kullanılmıştır.

$$
N D W I=\frac{(\text { Xgreen }- \text { Xnir })}{(\text { Xgreen }+ \text { Xnir })}
$$

Formülde (1) kullanılan Xgreen ve Xnir, Tablo 1 deki multispectral görüntülerin yeşil (green) ve NIR bandının yansıma değeridir (McFeeters, 1996). İndeks sonuçları -1 ile 1 arasında değişebilir. Pozitif değerler su yüzeylerine ve negatif değerler ise su olmayan yüzeylere işaret eder.
NDWI analizi ile Filyos Çayı Deltası için, farklı tarihlere ait sekiz adet kıyı çizgisi belirlenmiştir (Şekil 2). Filyos Çayı'nın denizle buluştuğu kısımlarda kıyı çizgisi, zeminin nem içeriği sulak ortam nedeni ile akarsu boyunca kara tarafina doğru sokulmaktadır. Çalışma kapsamında; deniz kıyı çizgileri üzerine odaklanılmıştır. Filyos Çayı'nın denize boşaldığı bölümde, akarsu kıyı alanı, akarsu kıyı çizgisi; akarsu süreçlerinin kontrolünde gelişir. Yansıma özelliklerinden kaynaklanan ve deniz kıyısı analizlerinde meydana gelen sapmalar için arazi çalışmalarındaki denizel ve karasal sediment depolanma özelliklerine ait tespitlere dayandırılan, manuel düzeltmeler yapılmıştır. Hisarönü ve Filyos Limanları'nın olduğu bölgedeki kıyı çizgileri; kıyı yapılarının spektral yansıtma özelliklerine bağlı olarak, şekillenmiştir.

"Kıyı Çizgisi Sayısal Analiz Sistemi (Digital Shoreline Analysis System-DSAS)"; kıyıdaki alansal değişimi, kıyı çizgisi değişimine bağlı olarak, kıyıdaki aşınım ve birikim perspektifinde tespit etmeye yönelik, ArcGIS yazılımında eklenti olarak kullanılabilen bir uygulamadır. DSAS yöntemiyle; kıyı çizgilerine ait vektör verileri kullanarak, bir zaman dilimi içerisinde, kıyı çizgisi değişim hızı istatistiklerinin hesaplaması gerçekleştirilir (Oyedotun, 2014; Joesidawati, 2016; Thinh \& Hens, 2017).

Kıyı çizgilerinin zaman içindeki değişimine dair farklı istatistikler oluşturan Digital Shoreline Analysis System (DSAS) analizi; kısa ve uzun zaman aralıklarında kıyıdaki aşınım ve birikimin belirlenmesinde etkili sonuçlar vermektedir. Bu çalışmada, ArcGIS 10.5 ile çalışabilen DSAS'ın 5.0 versiyonu kullanılmıştır. 1984 yılından 2020 yılına kadar, ortalama 5 yılda bir üretilen kıyı çizgileri ile birlikte, bu kıyı çizgilerine yaklaşık 100 metre uzaklıkta tampon (buffer) işlemi uygulanarak referans çizgisi (baseline) oluşturulmuştur. DSAS kapsamında kara ya da deniz tarafinda çizilerek kullanılabilen referans çizgisi, bu çalışmada kara yönünden çizilerek oluşturulmuştur. Referans çizgisi; kıyıyı tanımlayan kıyı elemanlarından biri olmayıp, DSAS analizi için oluşturulan ve aşınım/birikim değişiminin izlenmesi amaçIı oluşturulan kara tarafindaki buffer zon sınırıdır.

Üretilen kıyı çizgileri ve referans çizgileri DSAS veri tabanına uygun olarak düzenlenmiş, ardından 25 metre aralıklarla yaklaşık 460 profil hatt (transect) çıkarılmıştır. DSAS eklentisindeki yumuşatma (smoothing distance) sekmesi için 750 değeri kullanılarak profil hatlarındaki kesişmeler önlenmeye çalışılmıştır (Şekil 3). Ardından hesaplama sekmesi (calculate rates) kullanılarak SCE, NSM, EPR ve LRR istatistikleri gerçekleştirilmiştir. DSAS analizi ile üretilen; 'Shoreline Change Envelope' (SCE), 'Net Shoreline Movement' (NSM), 'End Point Rate' (EPR), 'Linear Regression Rate' (LRR), 'Weighted Linear

Tablo 1. Kıyı çizgisi tesbiti için kullanılan Landsat uydu görüntüleri ve bant özellikleri (USGS, 2021 den düzenlenmiştir). Table 1. Landsat satellite images and band features used for shoreline detection. (edited from USGS.)

\begin{tabular}{|c|c|c|c|c|c|}
\hline Uydu Görüntüleri & Tarih & Yörünge/Sıra & Bandlar & Dalga Boyu ( $\boldsymbol{\mu m})$ & Çözünürlük(m) \\
\hline Landsat 4-5 & $16 / 07 / 1984$ & & Band 2-Green & $0.52-0.60$ & 30 \\
(TM) & $18 / 08 / 1990$ & \multirow{2}{*}{$178 / 31$} & Band 3-Red & $0.63-0.69$ & 30 \\
& $31 / 07 / 1995$ & & Band 4-NIR & $0,76-0,90$ & 30 \\
\hline & $04 / 07 / 2000$ & & & & \\
Landsat 7 & $18 / 07 / 2005$ & \multirow{2}{*}{$178 / 31$} & Band 2-Green & $0.52-0.60$ & 30 \\
(ETM +) & $14 / 06 / 2010$ & & Band 3-Red & $0.63-0.69$ & 30 \\
& $12 / 08 / 2020$ & & & $0,77-0,90$ & 30 \\
\hline Landsat 8 & $22 / 07 / 2015$ & \multirow{2}{*}{$178 / 31$} & Band 3-Green & $0.53-0.59$ & 30 \\
(OLI/TIRS) & $04 / 08 / 2020$ & & Band 5-NIR & $0,85-0,88$ & 30 \\
\hline
\end{tabular}




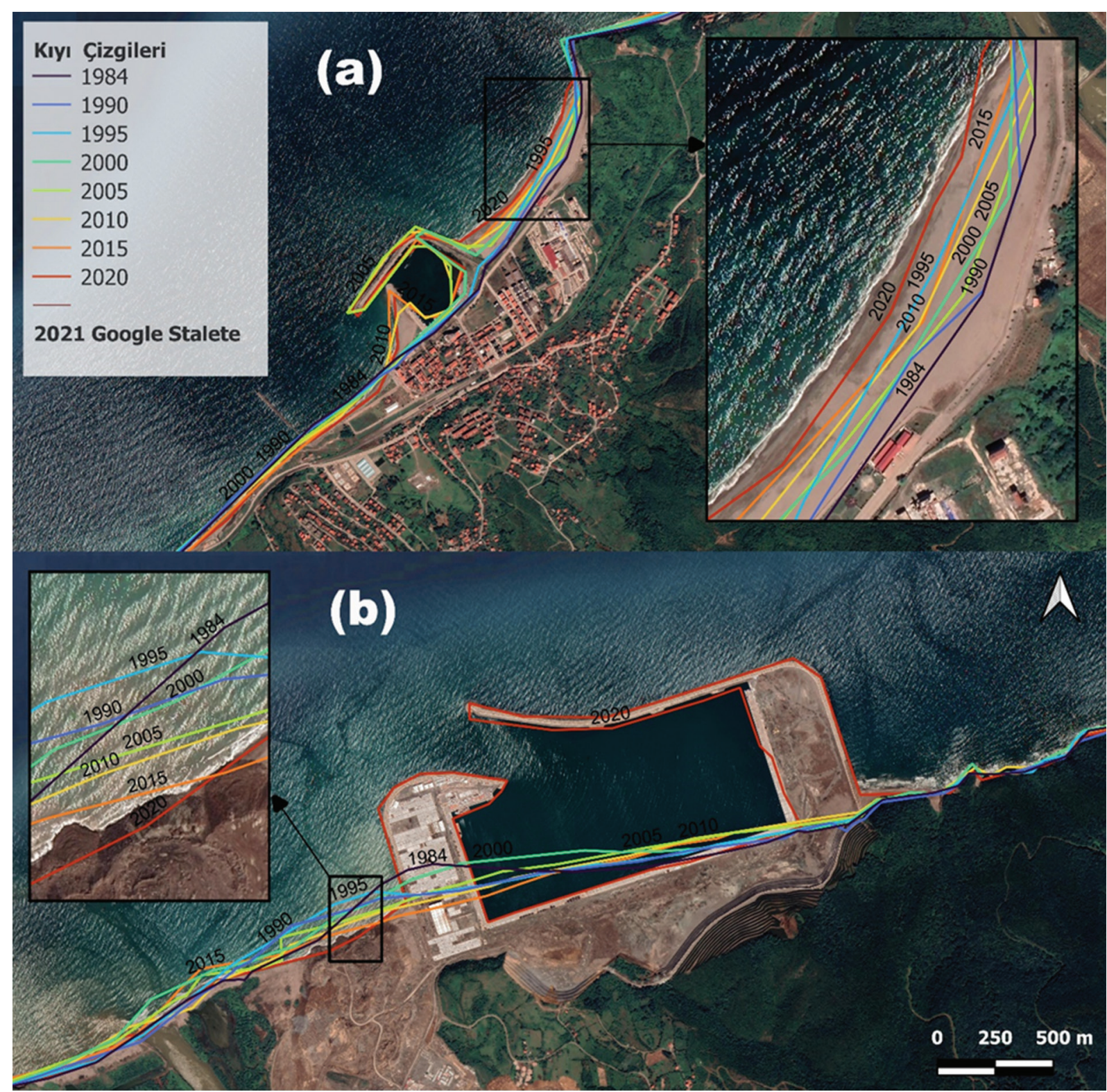

Şekil 2. Landsat uydu görüntülerinden üretilen farklı tarihlerdeki kıyı çizgileri (a. Hisarönü Balıkçı Barınağı, b. Filyos Limanı).

Figure 2. Shorelines on different dates produced from Landsat satellite imagery (a. Hisarönü Fishing Harbour, b. Filyos Port).

Regression' (WLR) istatistikleri son yıllarda birçok uluslararası çalışmada etkin olarak kullanılmıştır (Oyedotun, 2014; Joesidawati, 2016; Himmelstoss vd. 2018; Özpolat \& Demir, 2019). Tamamlayıc istatistik olarak ise 'R-squared Statistic', 'Standard Error of the Estimate', 'Uncertainty of End Point Rate' ve 'Standard Error of the Slope With Confidence Interval' olmak üzere çeşitli istatistikler DSAS 5.0 versiyonunda araştırmacıların kullanımına sunulmuştur (Kuleli, vd. 2011; Sheik \& Chandrasekar 2011; Sarwar \& Woodroffe, 2013; Oyedotun, 2014; Moussaid vd. 2015; Joesidawati, 2016; Oyedotun, 2016; Himmelstoss vd. 2018; Kılar \& Çiçek, 2018; Özpolat \& Demir, 2019).

Filyos Çayı mansabı ve çevresindeki kıyı boyunca değişikleri belirlemek amacı ile yapılan analizlerde SCE istatistiği; aşınım ve birikimi pozitif değerler ile metre $(\mathrm{m})$ cinsinden vermektedir. NSM istatistiği; en eski kıyı çizgisi ile en yeni kıyı çizgisi arasındaki mesafeyi metre $(\mathrm{m})$ cinsinden ifade eden sonuçlar vermektedir. EPR istatistiği; en eski kıyı çizgisi ile en yeni kıyı çizgisi arasındaki mesafenin zamana bölünmesini ifade eder ve met$\mathrm{re} / \mathrm{yll}(\mathrm{m} / \mathrm{y})$ cinsinden sonuçlar verir. LRR istatistiği; profil hattı ile kesişen bütün kıyı çizgilerinin zamana bölünmesini ifade eder ve metre/yıl (m/y) cinsinden sonuçlar vermektedir. NSM, SCE ve EPR istatistikleri için en az iki kıyı çizgisi kullanılırken LRR istatistiği için en az üç kıyı çizgisi kullanılması gerekmektedir (Moussaid vd. 2015; Joesidawati, 2016; Oyedotun, 2016; Himmelstoss vd. 2018; Kılar \& Çiçek, 2018; Duran, 2021).

Kıyıdaki plaj ve artkıyı alanlarına ait değişikleri belirleyebilmek için 16/07/1984 ve 12/08/2020 tarihli Landsat 4-5 ile Landsat 7 uydu görüntüleri tercih edilmiştir (Tablo 1). Uydu görüntülerindeki kırmızı bant (B3) amaca uygun spektral bant olup (Henrico vd. 2020), ArcGIS 10.5 yazılımının 'Image Analyst' menüsündeki 'Difference' aracı ile sınıflandırılmıştır. Sınıflamada; kumun spektral yansıtma özelliklerinden hareketle, görüntü piksel değerleri dikkate alınıp, kumul alanlarındaki farklılaşmalar belirlenmiştir.

\section{Bulgular}

3.1. Kıyı Çizgisi Değişim Analizleri

1984-2020 yıllarına ait 5 er yıllık periyotlar için DSAS yöntemi ile gerçekleştirilen kıyı çizgisi değişimi analizleri (Şekil 4; Şekil 5) içinde kıyı çizgisindeki en fazla ilerleme miktarı; 1995 - 


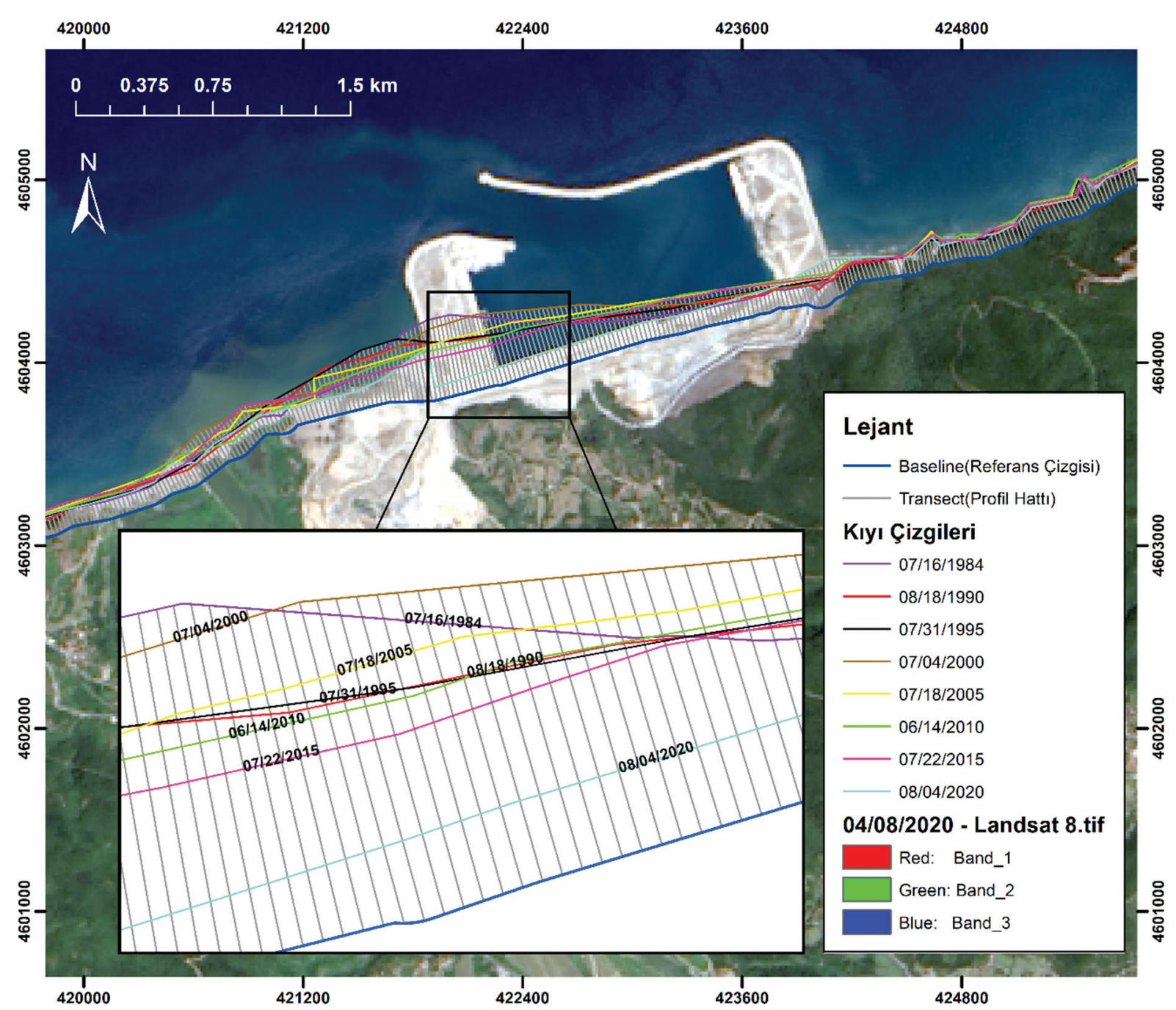

Şekil 3. Filyos Limanı ve yakın çevresinde DSAS yöntemi ile üretilen kıyı çizgisi hareketleri ve değişiklikleri.

Figure 3. Shoreline movements and changes produced with DSAS method at Filyos Port and its close vicinity.

2005-2010 periyodunda olduğu hesaplanmıştır. Bu ilerleme; NSM istatistiğine göre 152,38 m, EPR istatistiğine göre 31,05 $\mathrm{m} / \mathrm{y}$ olarak gerçekleşmiştir (Şekil 4, Tablo 2). Dalga ve akıntıların kontrolünde gelişen aşınıma bağlı olarak, kıyı çizgisindeki en büyük gerilemenin ise 2015 - 2020 periyodunda gerçekleştiği hesaplanmıştır. Bu gerileme DSAS analizinde; NSM istatistiğine göre $-156,73 \mathrm{~m}$, EPR istatistiğine göre ise $-31,11 \mathrm{~m} / \mathrm{y}$ olarak hesaplanmıştır (Şekil 4, Tablo 2). NSM ve EPR değerlerinin ortalamasını aldığımızda, değerlerin sıfir olması; aşınım ve birikimin eşit olduğu, sıfirdan pozitif ya da negatif uzaklaşması birikimin ya da aşınımın lehine fazla olduğunu göstermektedir. NSM ve EPR istatistiğinde en uç ortalama değerlerin NSM:
-23,50 ile EPR: -4,67 ile negatif olduğu hesaplanmıştır (Tablo 2). Standart sapma; uç değerlerin ortalamadan ne kadar uzaklaşıldığını göstermesi bakımından önemlidir. NSM ve EPR istatistiklerindeki en yüksek standart sapmalar ise NSM: 45,82 ve EPR: 9,09'dur (Tablo 2). Hem en düşük ortalama, hem yüksek standart sapma, hem de en yüksek aşınım miktarına sahip veriler 2015 - 2020 periyodunda gerçekleşmiştir (Tablo 2) (Şekil 4 ve 5). Filyos Limanı inşaatının 2014 yılı itibariyle başladığı düşünüldüğünde; liman yapımının kıyıdaki aşınım ve birikimin gelişimi üzerinde ne denli etkili olduğunu göstermesi bakımından önemlidir.

Tablo 2. 1984'den 2020'ye DSAS analizi ile hesaplanmış olan NSM ve EPR istatistikleri.

Table 2. NSM and EPR statistics from 1984 to 2020 calculated by DSAS analysis.

\begin{tabular}{|c|c|c|c|c|c|c|c|c|}
\hline \multirow[b]{2}{*}{ Yıllar } & \multicolumn{4}{|c|}{ NSM (m) } & \multicolumn{4}{|c|}{ EPR $(m / y)$} \\
\hline & Max & Min. & Ort. & S.S. & Max & Min. & Ort. & S.S. \\
\hline 1984-1990 & 118,19 & $-142,87$ & 0,95 & 34,91 & 19,41 & $-23,47$ & 0,16 & 5,73 \\
\hline 1990-1995 & 62,66 & $-23,51$ & 10,61 & 14,21 & 12,66 & $-4,75$ & 2,14 & 2,87 \\
\hline $1995-2000$ & 120,37 & $-76,35$ & 14,24 & 37,42 & 24,42 & $-15,49$ & 2,89 & 7,59 \\
\hline $2000-2005$ & 60,75 & $-95,02$ & $-8,66$ & 27,74 & 12,06 & $-18,87$ & $-1,72$ & 5,51 \\
\hline $2005-2010$ & 152,38 & $-80,59$ & 0,55 & 28,96 & 31,05 & $-16,42$ & 0,11 & 5,90 \\
\hline 2010-2015 & 110,38 & $-133,06$ & $-7,11$ & 27,11 & 21,63 & $-26,07$ & $-1,39$ & 5,31 \\
\hline $2015-2020$ & 89,40 & $-156,73$ & $-23,50$ & 45,82 & 17,74 & $-31,11$ & $-4,67$ & 9,09 \\
\hline
\end{tabular}




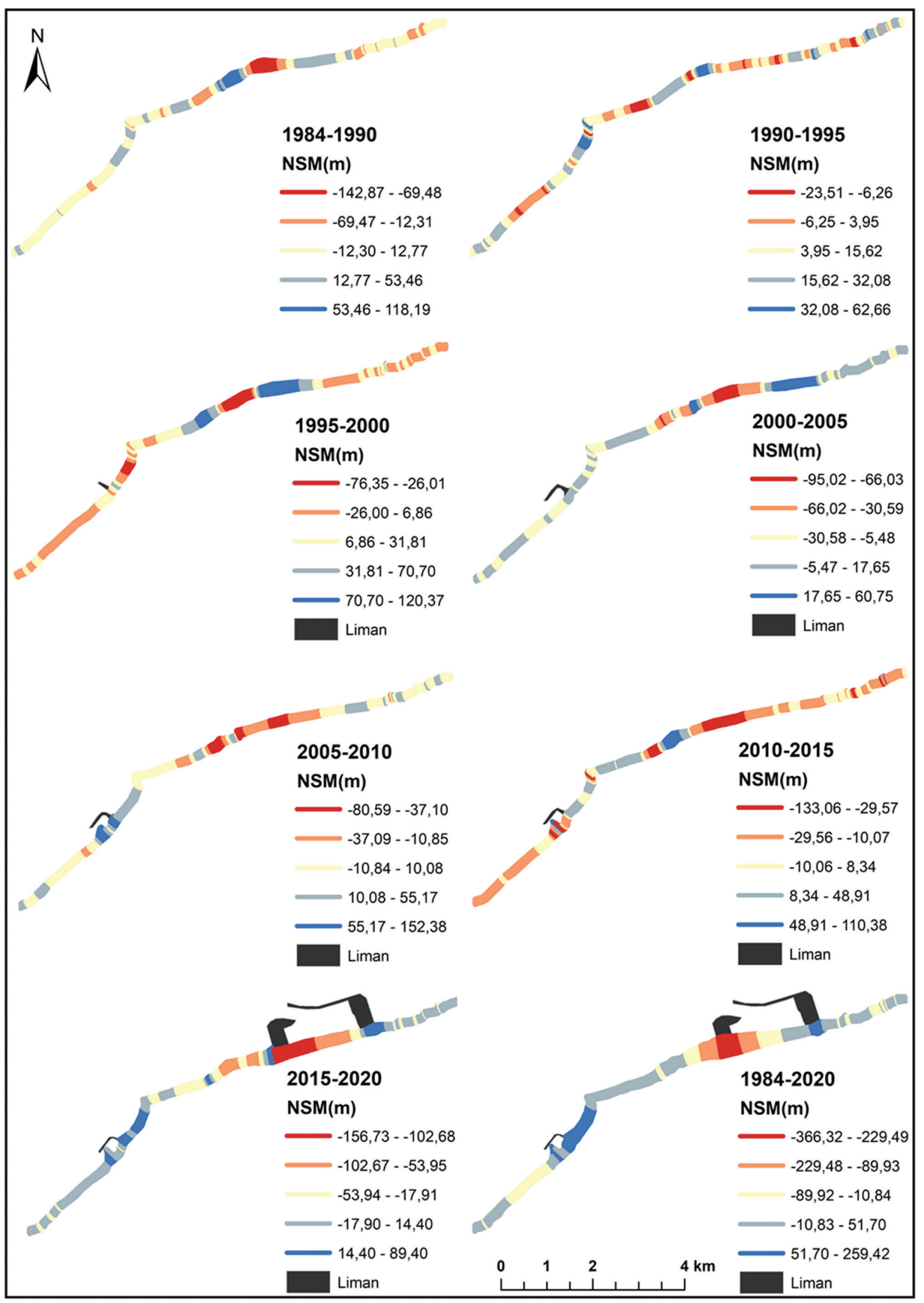

Şekil 4. 1984'den 2020'ye kıyı çizgisi değişimini gösteren NSM haritası (Duran, 2021 den güncelleştirilmiştir).

Figure 4. NSM map showing shoreline change from 1984 to 2020 (updated from Duran, 2021). 


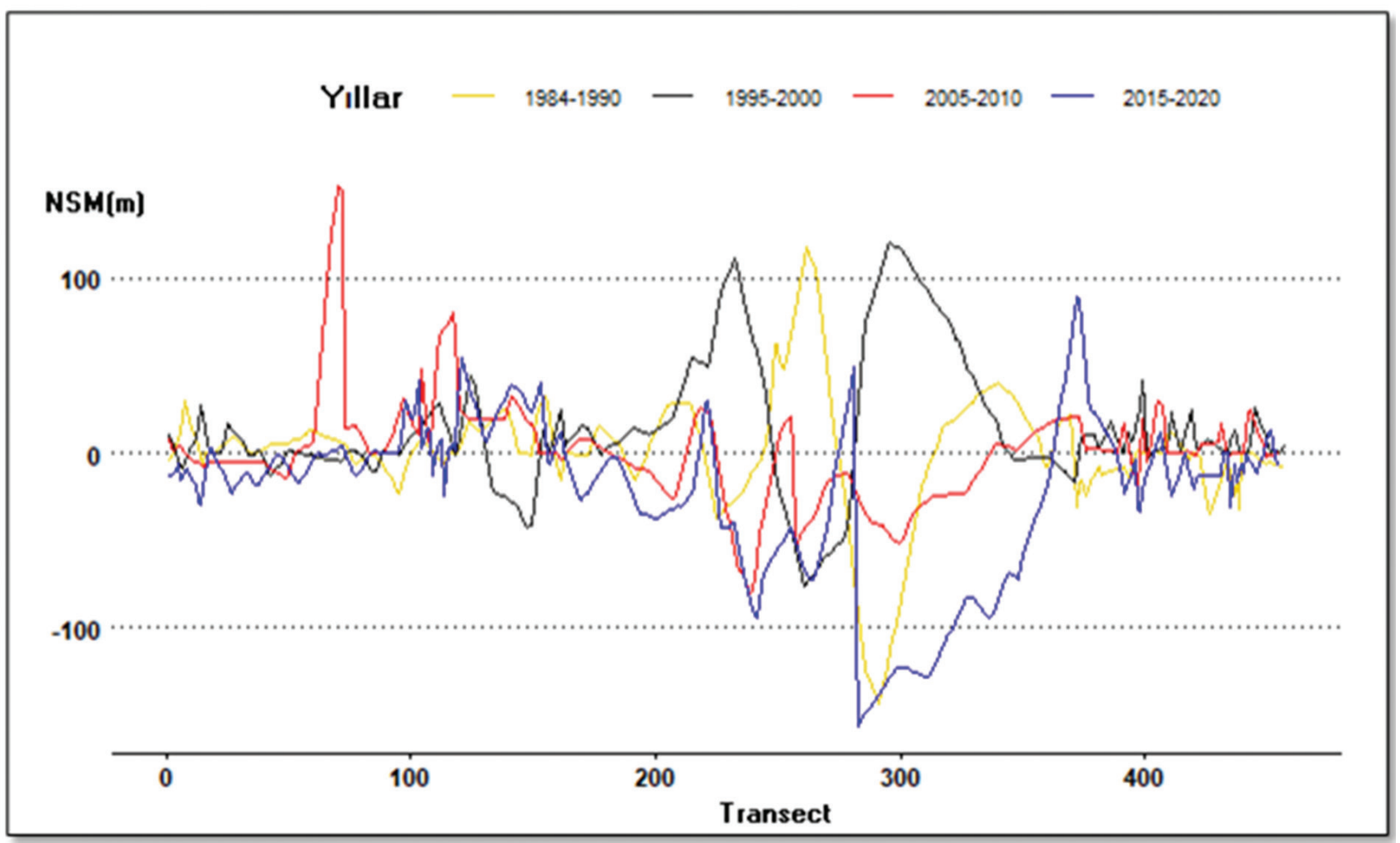

Şekil 5. Farklı tarihlerdeki lokasyon-kıyı çizgisi değişim mesafesi (NSM) grafiği.

Figure 5. Graph of location-shoreline change distance (NSM) on different dates.

Liman inşaatlarının kıyıdaki aşınım ve birikimin gelişimi üzerindeki etkilerini anlamak üzere, $1984-2000$ ve 2000-2020 periyotlarına ait kıyı çizgileri dikkate alınarak analiz edilmiştir (Şekil 6). 1984-2000 periyodunda, maksimum kıyı çizgisi ilerlemesi; NSM: 63,46-102,51 m ile 224-249 profil hatları arasında kalan, Filyos Çayı mansap kısmında meydana gelmiştir (Tablo 3). Kıyı çizgisindeki bu değişikliğin hızı; EPR: 3,25-6,42 m/y olduğu görülmektedir. 1984-2000 periyodunda maksimum kıyı çizgisi gerilemesi; NSM: -18,93 ile $-51,90$ m değerleriyle (Tablo 3, Şekil 6), 275-292 numaralı profiller arasına denk gelen Filyos Çayı'nın yaklaşık 1,3 km doğusunda meydana geldiği anlaşılmıştır. Kıyı çizgisindeki bu gerilemenin hızı ise EPR: $-1,19$ ile $-3,25 \mathrm{~m} / \mathrm{y}$ olarak hesaplanmıştır. 1984-2020 periyodunda NSM ve EPR değerlerinin ortalamaları sırayla 25,80 ile 1,62 iken, standart sapmaları sırayla 28,55 ve 1,79 'dur (Tablo 3 ).

2000 - 2020 periyodu NSM değerlerine bakıldığında; kıyı çizgisi maksimum ilerlemesi; 112-155 numaralı profilleri kapsayan Hisarönü Limanı'nın doğu kısmında, 29,04-228,04 m,
EPR değeri ise 1,45-11,35 m/y olarak hesaplanmıştır (Tablo 3, Şekil 6). 2000-2020 periyodu NSM değerlerine ait en yüksek aşınımın 282 - 317 profil hatları arasında kalan Filyos Limanı'nın bat kısmında -195,34 ile -313,30 metre aralığında, EPR değeri ise $-9,73$ ile $-15,60 \mathrm{~m} / \mathrm{y}$ arasında olduğu görülmüştür (Tablo 3, Şekil 6). 2000-2020 periyodunda NSM ve EPR değerlerinin ortalamaları sırayla -39,66 ile -1,97 iken, standart sapmaları NSM: 87,23 ve EPR: 4,34 olarak hesaplanmıştır (Tablo 3). 1984-2020 periyoduna bakıldığında en fazla birikim; NSM istatistiğinde $259,42 \mathrm{~m}$, EPR istatistiğinde $7,20 \mathrm{~m} / \mathrm{y}$, LRR istatistiğinde ise 7,80 m/y dır. 1984-2020 periyodunda en fazla aşınım; NSM'de -366,32 m, EPR'de -10,16 m/y ve LRR'de -7,54 $\mathrm{m} / \mathrm{y}$ dır (Tablo 3). Son 20 yıllık periyoda ait istatistiklere bakıldığında; NSM ve EPR istatistiklerinde maksimum, minimum, standart sapma değerleri daha yüksekken, ortalama değeri düşüktür. Bu sonuçlar; özellikle liman yapılarının, kıyı morfodinamik süreçlerini net bir şekilde etkileyerek, kıyıda (kıyı çizgisi ve kıyının bölümleri üzerinde) morfolojik ve alansal değişimlere neden olduğunu göstermektedir (Tablo 3) (Şekil 6).

Tablo 3. $1984-2000,2000-2020$ ve 1984-2020 periyotları için DSAS analizi ile hesaplanan NSM, EPR, LRR istatistikleri.

Table 3. NSM, EPR, LRR statistics calculated by DSAS analysis for the periods 1984-2000, 2000-2020 and 1984-2020.

\begin{tabular}{|c|c|c|c|c|c|c|c|c|c|}
\hline 1984-2000 & $\operatorname{NSM}(\mathrm{m})$ & $\operatorname{EPR}(\mathrm{m} / \mathrm{y})$ & $2000-2020$ & $\operatorname{NSM}(\mathrm{m})$ & $\operatorname{EPR}(\mathrm{m} / \mathrm{y})$ & 1984-2020 & $\operatorname{NSM}(\mathrm{m})$ & $\operatorname{EPR}(\mathrm{m} / \mathrm{y})$ & $\operatorname{LRR}(\mathrm{m} / \mathrm{y})$ \\
\hline Max & 102,51 & 6,42 & Max & 228,04 & 11,35 & Max & 259,42 & 7,20 & 7,80 \\
\hline Min. & $-51,9$ & $-3,25$ & Min. & $-313,30$ & $-15,60$ & Min. & $-366,32$ & $-10,16$ & $-7,54$ \\
\hline Ort. & 25,80 & 1,62 & Ort. & $-39,66$ & $-1,97$ & Ort. & $-13,55$ & $-0,38$ & $-0,08$ \\
\hline S.S. & 28,55 & 1,79 & S.S. & 87,23 & 4,34 & S.S. & 88,79 & 2,46 & 2,10 \\
\hline
\end{tabular}






Şekil 6. 1984-2000, 2000-2020 ve 1984-2020 periyotları için DSAS analizi ile üretilen NSM, EPR ve SCE haritaları (Duran, 2021 den güncelleştirilmiştir). Figure 6. NSM, EPR and SCE maps produced by DSAS analysis for the periods 1984-2000, 2000-2020 and 1984-2020 (updated from Duran, 2021).

\subsection{Plaj ve Kıyı Kumulları Alansal Değişim Analizi}

Kıyı Çizgisi ile Karasal Kıyı Kenar Çizgisi arasında kalan alanın (ön kıyının su dışında kalan alanı ile art kıyı alanı) değişim haritası; 16 Temmuz 1984 tarihli Landsat 4-5 (TM) Band 3 ve 12 Ağustos 2020 tarihli Landsat 7 (ETM +) Band 3 verileri, ArcGIS 10.5 "Image Analyst" uzantısı "Difference" aracı kullanılarak oluşturulmuştur (Şekil 8). Bu analiz; görüntü piksellerinin birebir karşılaştırılması sonucu aralarındaki farklılık ve benzerlik tanımlaması ile yapılmıştır. Uygulama; önceki tarihli görüntü pikseli ile sonraki tarihli görüntü pikseli karşılaştırılmasıyla gerçekleştirilir. Piksellerin değerleri birbirinden farklıysa; ilk görüntüdeki pikselin değeri, üretilen sonuç haritasındaki piksel değeri olarak kullanılmıştır. Farklı tarihlerdeki görüntülerde, hedef piksel değerleri birbirinin aynısıysa; yeni üretilen haritada bu pikselin değeri " 0 " olarak kullanılmıştır. Piksel yansıma farklılıklarına dayalı, fark sınıflama tekniği ile üretilen bu haritalardaki koyu yeşil renk kıyıdaki alansal büyümeyi (birikim alanı), koyu kırmızı renk kıyıdaki daralmayı (aşınım alanı) ifade eder. Şekil 8 deki sarı ve açık yeşil renkler ise değişim göstermeyen ya da değişimin daha az olduğu kıyı alanlarını temsil etmektedir.

Analiz sonuçları; 16 Temmuz 1984 tarihli Landsat 4-5 (TM) görüntüsü kıyılarında $2,11 \mathrm{~km} 2$ olan plaj ve kumul alanının, 12 Ağustos 2020 tarihli Landsat 7 (ETM +) görüntüsünde $\% 18,48$ oranında azalarak, 1,72 km2 ye gerilediğini göstermektedir (Şekil 8). Filyos Limanı batısındaki ve liman içindeki koyu kırmızı renk alanı (aşınma alanı) liman inşaatı projesi kapsamında antropojenik olarak gerçekleşen kazıya bağlı değişikliktir (Şekil 3) ve $\% 18,48$ oranındaki azalmanın önemli kısmını temsil etmektedir. 

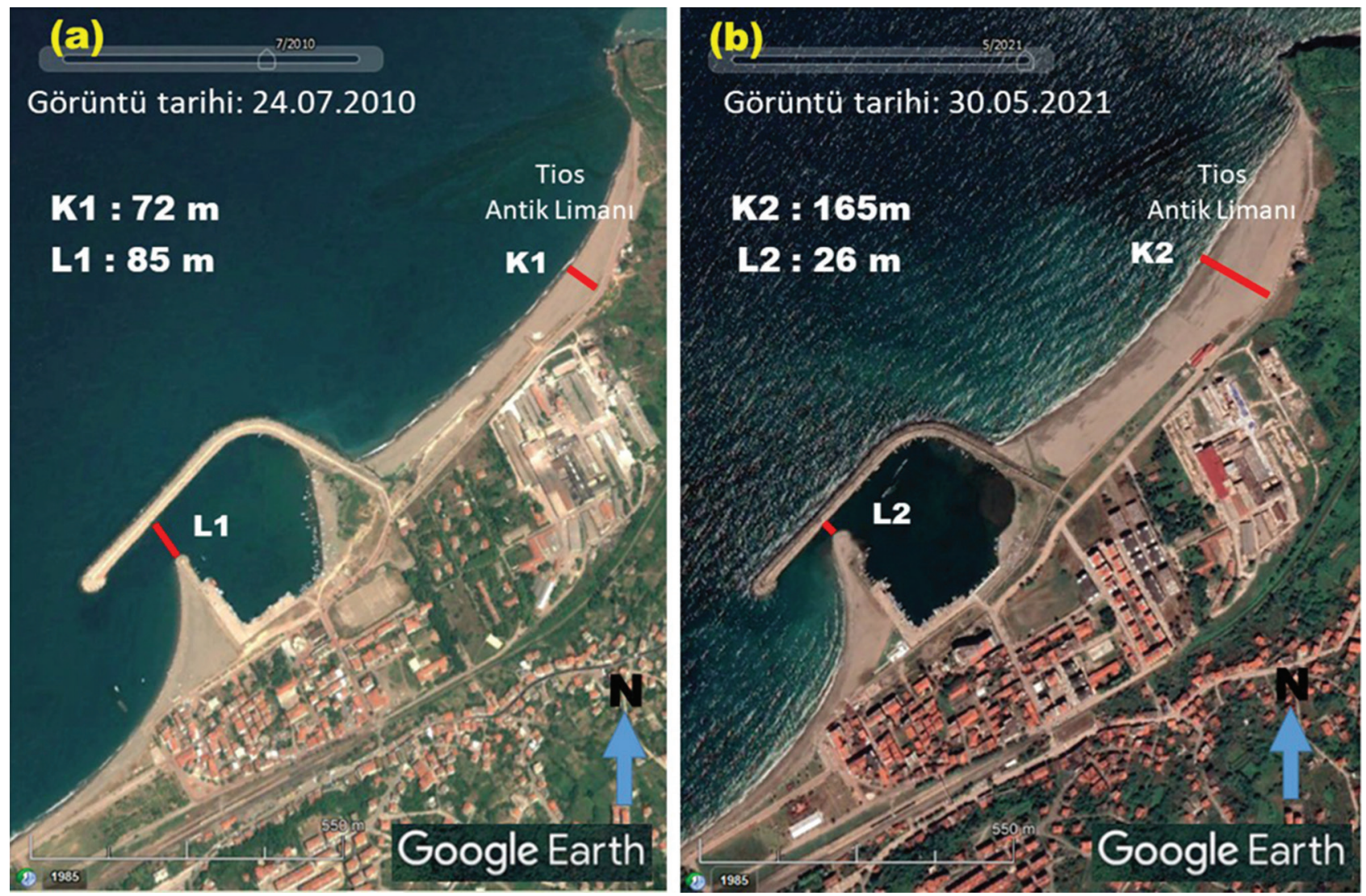

Şekil 7. Hisarönü Balıkçı Barınağının Google Earth uydu görüntüleri (a) 24/07/2010, (b) 30/05/2021.

Figure 7. Google Earth satellite images of Hisarönü Fishing Harbour (a) 24/07/2010, (b) 30/05/2021.

4. Kıyı morfolojisindeki değişimin değerlendirmesi ve öngörüler

Bu çalışma kapsamında gerçekleştirilen Coğrafi Bilgi Sistemleri ve Uzaktan Algılama analizlerinin sonuçları; Filyos Çayı Deltası kıyı çizgisinin zaman içindeki hareketliliğini, plaj ve artkıyı kumullarındaki alansal değişimini, bu değişikliklerin oransal dağılışları ile hızlarını açıkça göstermektedir. Bu sonuçlar; delta kıyısı üzerinde bazı tehlikeler ve riskleri hakkında öngörülerin yapılmasına imkân vermektedir. Bu öngörülerden biri; kum birikimi problemi nedeni ile yakın gelecekte Hisarönü Balıkçı Barınağı ve Filyos Limanının kullanımında problemlerin başlayacağı ile ilgilidir. Diğer öngörü ise büyük bölümü su altındaki yakınkıyı ve önkıyı içinde, bir bölümü ise su dışındaki önkıyı ve artkıyı içinde olan Tios antik limanının kum örtüsü altında kalma tehlikesine ait yüksek risktir.

Kıyıyı belirleyen sınırlar (kıyı çizgisi ve kıyı kenar çizgileri), bu sınırlar ile tanımlanan kıyının bölümleri ve bu kıyı elemanlarının şekillendirdiği kıyı tipi (Stanica \& Ungureanu, 2010; Turoğlu, 2017); yapısal özellikler, güncel morfodinamik etken ve süreçlere, ilaveten insan faktörünün kontrolünde gerçekleşen aktif gelişim, değişim içindedir. Kıyıya yapılan dolgular, koruma yapıları ve benzeri her türlü projeler bu değişimin antropojenik tetikleyicileri olurlar. Özellikle liman yapıları kıyı çizgisinin değişmesine dolayısıyla plaj ve artkıyı kumul alanlarının ve kıyı tipinin farklılaşmasına neden olur (Turoğlu 2019). Filyos Deltası kıyılarında yapılan Hisarönü Balıkçı Barınağı ve Filyos limanı bu kıyılarda; antropojenik tetikleme ile doğal etkenlerin kontrolünde gelişen aşınma, taşınma ve birikme süreçlerinin farklılaşmasına neden olmuştur (Şekil 5 ve 6). Bu farklılaşmada kıyı çizgisinin ilerlemesinin en yoğun gerçekleştiği kısım (Şekil
3); Hisarönü Balıkçı Barınağı'nın hemen doğusunda Şekil 8 de görülen koyu yeşil alandır. Kıyıdaki bu değişikliğin rakamsal boyutları "3.1. Kıyı çizgisi değişim analizleri" başlığı altında verilmiştir. Kıyı çizgisindeki ilerlemeye bağlı olarak plaj ve artkıyı kumul alanındaki genişlemenin gerçekleşmesinde; Hisarönü Balıkçı Barınağı'nın inşa edilmesinin tetikleme etkisiyle aktifleşen kıyı morfodinamiğinin değişmesi rol oynamıştır. Kıyıdaki bu değişimin tarih ve hı ilişkilendirmesi bu değerlendirmeyi desteklemektedir. Filyos Limanının günümüze yakın tarihlerde tamamlanmasına rağmen, bu kesimde de kıyı çizgisindeki değişimler dikkat çekmektedir (Şekil 5 ve 6). Filyos Limanı'nın inşaat sırasında yakınkıyı, önkıyı ve artkıyı alanlarında yapılan kazı ve dolgular, deltanın bu bölümünde, kıyının "Doğal Geniş-Alçak kıyı" tipinden, "Yapay Dar-Yüksek kıyı" tipine dönüşmesinin nedeni olmuştur. Kıyıda etkili olan morfodinamik etkenler de değişen bu kıyı tipi özelliklerine bağıı olarak yeniden kendi süreç sistemini tesis etmiştir. Filyos Limanı ve etki alanının boyutları itibarıyla kıyı üzerindeki etki derecesinin de bu boyutlarla uyumlu olduğu ve olmaya devam edeceği kabul edilmektedir.

Bir akarsudan denize deşarj olan sedimentlerin yayılış ve taşınma istikametleri kıyı akınt sistemleri için güvenilir göstergeler olarak kabul edilmektedir (Ouillon, 2018; Morrone \& letto, 2021). Genel anlamda Sakarya nehrinden, Bartnn nehrine kadar Karadeniz kıyıları boyunca sediment yayılış ve taşınma yönü güneybatıdan, kuzey doğu istikametinde olup, bu sediment yayılış ve taşınma yönü Filyos Çayı sedimentleri için de geçerlidir (Norman, 1977). Bu durum Şekil 9 daki farklı tarihlere ait Google Earth görüntüleri ile de doğrulanmaktadır. Filyos Limanı inşaat öncesinde, kum birikiminin, su dışındaki önkıyının ve artkıyının en geniş alana sahip olduğu bölüm; Filyos Limanı doğu dalgakıranının olduğu yerde gelişmiştir (Şekil 2 ve 


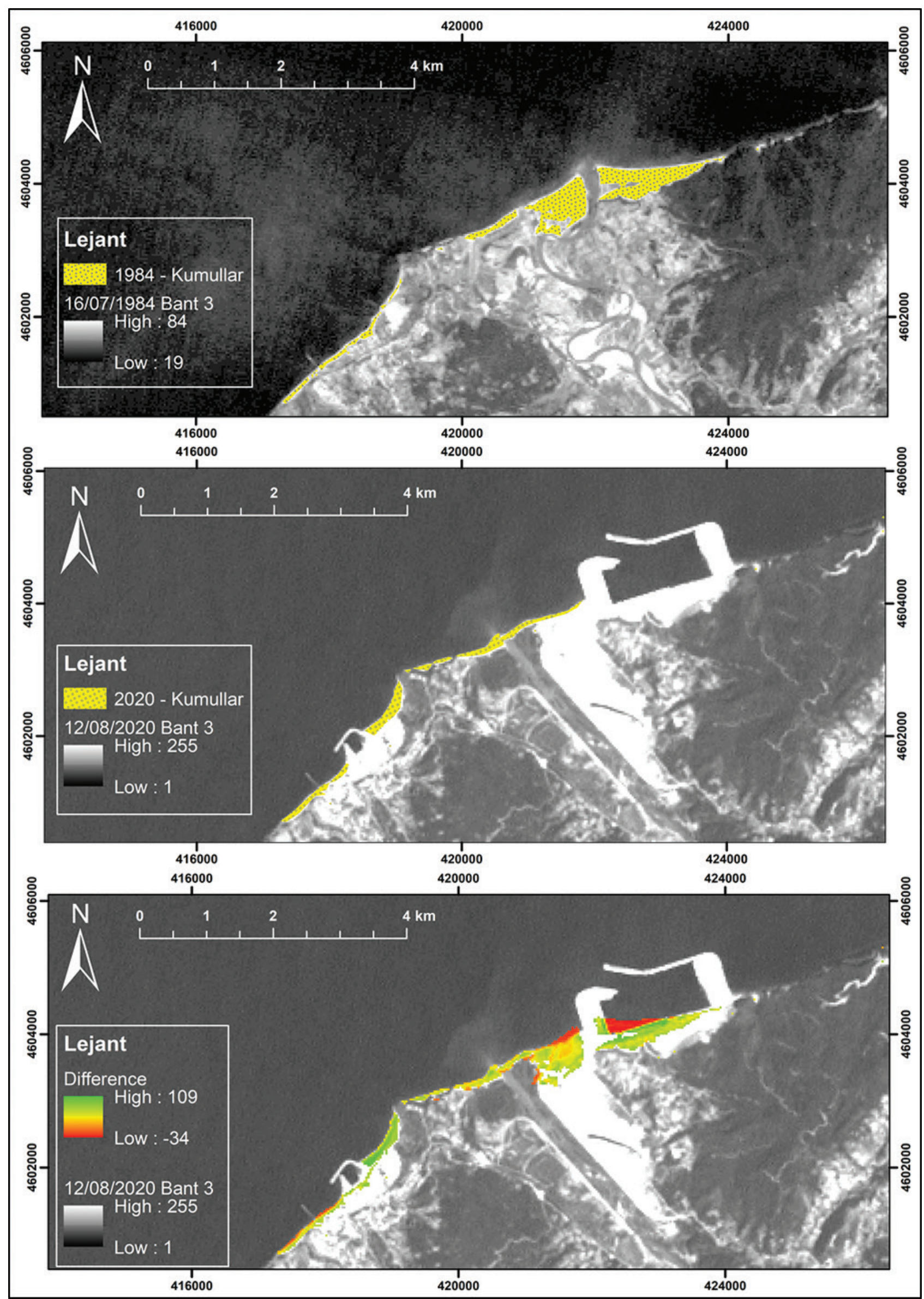

Şekil 8. Filyos Nehri Deltası kıyılarında plaj ve artkıyı kumullarındaki alansal değişimin analizi.

Figure 8. Analysis of the areal changes in beach and backshore sands on the shores of the Filyos River Delta. 

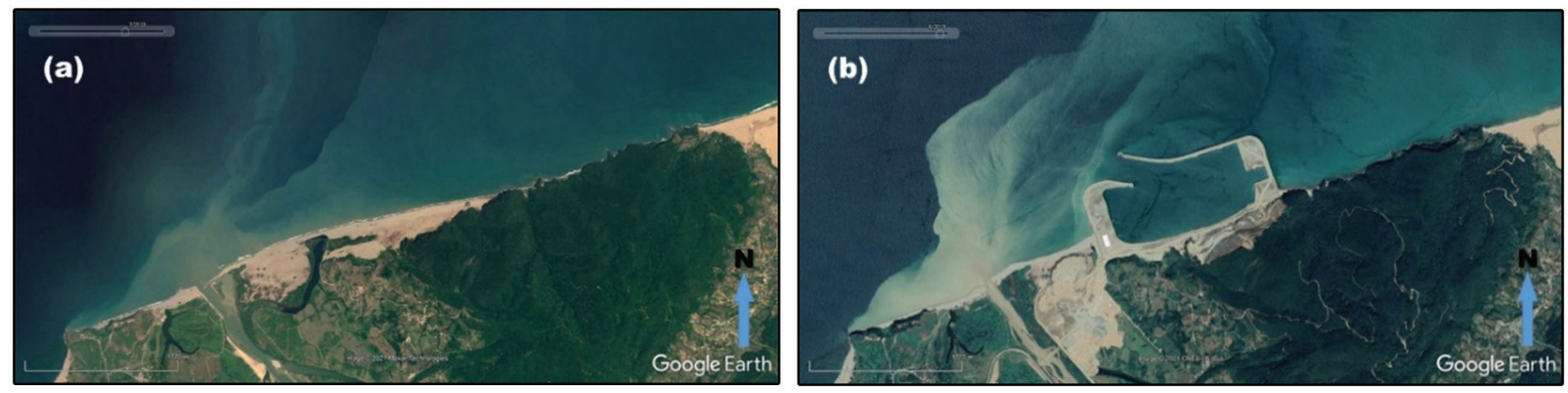

Şekil 9. Akınt ve sediment taşınma yönünü gösterir 24/07/2010(a) ve 28/06/2019(b) tarihli Google Earth uydu görüntüleri.

Figure 9. Google Earth satellite images dated 24/07/2010(a) and 28/06/2019(b) showing current and sediment transport direction.

3). Güneybatıdan kuzeydoğu yönündeki kıyıboyu akıntıları ile taşınan sedimentler, inşaat daha uzun süre önce tamamlanmış olan Hisarönü Balıkçı Barınağının batı dalgakıranı önünde kum birikimine ve kum birikiminin gelişerek kıyı oku şeklinde liman girişine doğru gelişmesine neden olmuştur (Şekil 7). Değişen akıntı sistemleri nedeni ile Hisarönü Balıkçı Barınağının ağız kısmında gerçekleşen kum birikimi hızla devam etmektedir.

Kıyı çizgisi ilerlemesinin ve kum birikiminin etkili olduğu bir başka örnek ise Hisarönü Balıkçı Barınağının hemen doğusundaki kıyı zonudur. DSAS analiz sonuçları deltanın bu bölümündeki yakın plaj ve artkıyı bölümlerinde, kum birikime bağlı alansal genişleme tespit edilmiştir (Şekil 3, 5 ve 7). Hisarönü Balıkçı Barınağı'nın yaklaşık 1 km doğusundaki Tios Antik Kenti; liman surları, Roma dönemi toprak üstü yapıları, savunma kulesi, su kemeri, tiyatro ve antik liman ile Karadeniz için önemli arkeolojik, tarihi ve kültürel bir değer oluşturmaktadır (Yıldırım, 2015; Yüksel \& Atasoy, 2007; Yıldırım, 2017). Tios an- tik limanı (Şekil 10a) bu arkeolojik mirasın önemli bir bileşenini oluşturmaktadır. Tios antik limanın bulunduğu kıyının 2010 ve 2014 yıllarına ait kıyı çizgilerinde belirgin bir farklılaşma görülmezken, 2018 ve 2021 yıllarına ait kıyı çizgilerinin hızlı bir şekilde ilerlediği belirlenmiştir (Şekil 10b). Hisarönü Balıkçı Barınağının yapılması ile birlikte kıyının alansal büyümesine neden olan hızlı bir kum birikimi yönünde değişimi tetiklediği (Şekil 5 ve 6) kıyı çizgisi ilerlemeleri ile anlaşılmaktadır (Şekil 10b).

Altlık olarak kullanılan 24.07.2010, 22.04.2014, 23.04.2018, 30.05.2021 tarihlerine ait Google Earth görüntülerinden DSAS yöntemi kullanılarak, $10 \mathrm{~m}$ aralıklarla oluşturulan profillerden elde edilen kıyı çizgisi ilerleme mesafesi (NSM) ile ilerleme hız (EPR) değerleri (Tablo 4); Tios Antik Limanı'nın istikrarlı bir şekilde dolduğunun, kıyı çizgisi maksimum ilerlemesinin (NSM) ve ilerleme hızının (EPR) 2014 sonrasında, öncesine oranla en az 2 kat arttı̆ı (Tablo 4) ve antik liman yapılarının kum örtüsü altında kalacağının kanıtlarıdır.
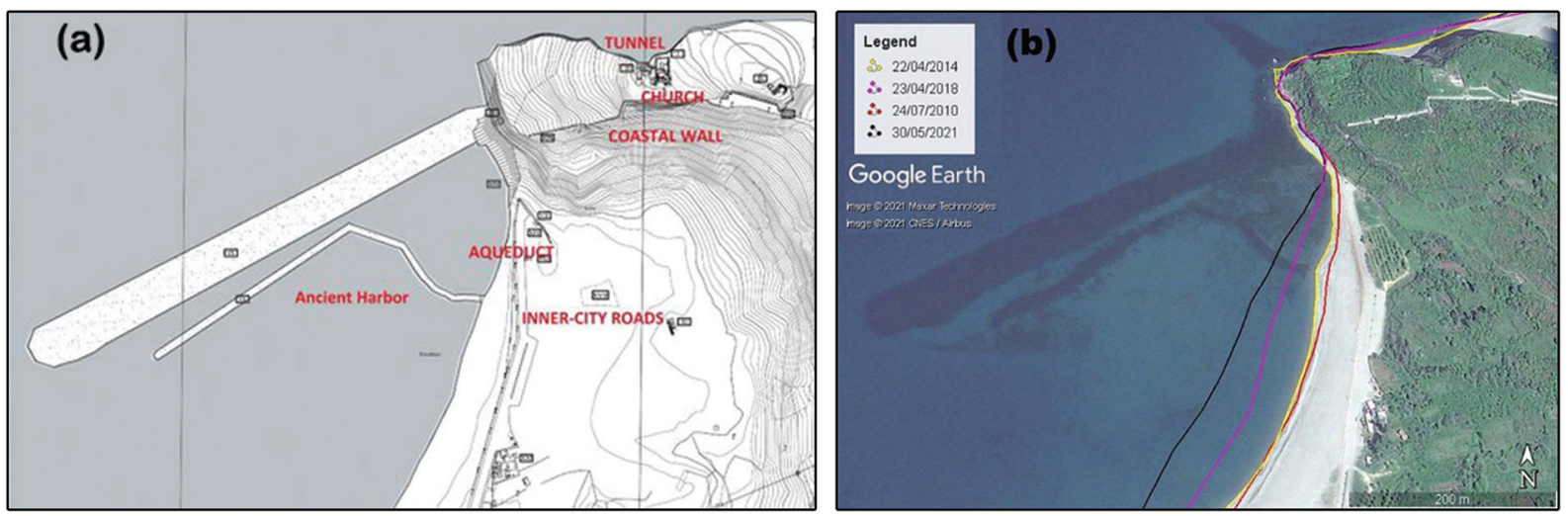

Şekil 10. (a) Tios antik limanı ve yakın çevresinin planı (Yıldııım, 2015; Yıldııı, 2017). (b) Tios antik limanı ve yakın çevresi kıyılarının farklı tarihlere ait kıyı çizgileri (Altlık görüntü 22.04.2014 tarihlidir).

Figure 10. (a) The plan of the ancient Tios Port and its close surroundings (YIldırım, 2015; YIldırım, 2017). (b) Shorelines of the ancient Tios Port and its close vicinity from different dates (Base image is dated 22.04.2014).

Tablo 4. Tios antik limanı ve yakın çevresinde 2010-2014, 2014-2018 ve 2018-2021 periyotlarına ait DSAS analizleri ile hesaplanan kıyı çizgisi değişim (NSM ve EPR) istatistikleri.

Table 4. Shoreline change (NSM and EPR) statistics around the ancient Tios Port for the 2010-2014, 2014-2018 and $2018-2021$ periods calculated by DSAS analysis.

\begin{tabular}{lll|lll|lll}
\hline 2010-2014 & NSM $(m)$ & EPR $(\mathrm{m} / \mathrm{y})$ & $\mathbf{2 0 1 4 - 2 0 1 8}$ & $\mathrm{NSM}(\mathrm{m})$ & EPR $(\mathrm{m} / \mathrm{y})$ & $\mathbf{2 0 1 8 - 2 0 2 1}$ & $\mathrm{NSM}(\mathrm{m})$ & EPR $(\mathrm{m} / \mathrm{y})$ \\
\hline Max & 25,18 & 6,72 & Max & 46,70 & 11,67 & Max & 42,07 & 13,56 \\
Min. & $-3,68$ & $-0,98$ & Min. & $-22,91$ & $-5,72$ & Min. & $-2,84$ & $-0,92$ \\
Ort. & 6,77 & 1,81 & Ort. & 18,62 & 4,65 & Ort. & 17,23 & 5,56 \\
S.S. & 6,13 & 1,64 & S.S. & 20,48 & 5,12 & S.S. & 16,04 & 5,17 \\
\hline
\end{tabular}




\section{Sonuç}

1984-2020 yılları için CBS ve UZAL teknolojileri kullanılarak yapılan kıyı çizgisi belirleme analiz sonuçları; (a) Özellikle delta kıyılarının liman inşaatı bölümlerinde kıyı çizgisi, kıyının bölümleri ve kıyı tipi değişmelerine, (b) liman dalgakıranlarına mücavir kıyılardaki önkıyı ve artkıyı alanlarında farklılaşmalara, (c) liman inşaatları ile birlikte, kıyı çizgisi ve kıyı alanı değişikliğinin çok daha hızlandığına işaret etmektedir.

Çalışma kapsamında yapılan kıyı çizgisi analizlerine göre; 1984-2020 tarihleri (36 yıllık dönem) için -299,49 m ile -366,32 $\mathrm{m}$ arasında değişen kıyı aşınımı hesaplanmıştır. Bu gerilemenin -156 m ile $-102,68 m$ lik bölümünün sadece $2015-2020$ yıllarında gerçekleştiği görülmüştür. Bu dikkat çekici değişikliğin özellikle Filyos Limanı proje sahasında, liman inşaat çalışmaları ile antropojenik olarak gerçekleştiği anlaşılmaktadır.

Kum birikimi ile gerçekleşen kıyı çizgisi ilerlemesi ve dolayısıyla kıyıdaki alansal büyüme 1984-2020 tarihleri için 51,70 m ile 259,42 m arasında değişen mesafelerde, Hisarönü Balıkçı Barınağının doğu kıyılarında gerçekleşmiştir. Aynı kıyılardaki kıyı çizgisi ilerlemesi 2015-2020 yıllarında da 14,40 - 89,40 m lik yer değiştirmeyle, kıyıdaki kum birikim alanının büyümesi şeklinde devam etmiştir. 36 yıllık kıyı çizgisi değişim trendi esas alındığında, Hisarönü Balıkçı Barınağı inşaat sonrasındaki belirgin kıyı çizgisi ilerleme miktarı (NSM) ve hızı (EPR) istikrarlı değişimi dikkat çekmektedir.

Hisarönü Balıkçı Barınağının doğu dalgakıranı önündeki kum birikim alanın giderek hızlı şekilde büyümesi, özellikle son 10 yıllık süre içinde barınak giriş mesafesini $85 \mathrm{~m}$ den $26 \mathrm{~m}$ ye düşürmüştür. Yıllık $\pm 5 \mathrm{~m}$ lik ilerleme hızının bu şekilde devam etmesi halinde, yakın gelecekte, Hisarönü Balıkçı Barınağı girişinin kapanma tehlikesinin yüksek riski altında olduğu öngörülmektedir.

Bir arkeolojik miras olarak; Tios Antik Kenti'ne ait bir bölümü su altında kalmış olan antik liman, Hisarönü Balıkçı Barınağının doğusundaki kıyı çizgisi ilerlemesine bağlı kum birikimi altında kalma tehlikesinin yüksek riski ile karşı karşıyadır. 2010-2021 tarihleri içinde kıyı çizgisinin düzenli şekilde ilerlediği, kıyı alanının genişlediği ve antik limanın yıldan yıla kum örtüsü altında kaldığı görülmektedir. 2010-2014 periyodunda 1,81 m/yıl olan ortalama ilerleme hızının, 2014-2018 döneminde 4,65 m/ yıl ve 2018-2021 yılları döneminde ise daha da artarak 5,56 m/ yıl a ulaşması tehlikenin boyutunu açıkça ifade etmektedir. Kıyı çizgisinin bu yıllık ilerleme eğiliminin aynı kalması halinde; günümüzde yakın kıyı ve ön kıyının su altındaki liman yapılarının, yakın gelecekte kıyı çizgisi ve karasal kıyı kenar çizgisi arasındaki kıyı alanının kum örtüsü altında kalması öngörülmektedir.

\section{Kaynakça}

Aksoy, E., \& Yıldırım, Ş. (2017). Rise and fall of Tios-Tieion. Materials Science and Engineering, 245. https://iopscience.iop.org/article /10.1088/1757-899X/245/7/072013

Atş, E., \& Çelikoğlu, Ş. (2019). Sosyo-ekonomik ve çevresel yönleriyle Filyos Vadi Projesi. Social Sciences Studies Journal (Sssjournal), 29, 49-68. http://www.sssjournal.com/DergiTamDetay. aspx?ID $=1188$

Avcı, M., \& Avcı, S. (2001). Limanların kıyı alanları üzerindeki etkilerine bir örnek: Filyos Limanı Projesi. İçinde E. Özhan \& Y. Yüksel (Eds.) Türkiye'nin Kıyı ve Deniz Alanları III. Ulusal Konferansı.

Çetinkaya, M. (2012). Filyos Vadisi Projesi. 1-37. Bat Karadeniz Kalkınma Ajansı. http://bakkakutuphane.org/upload/flip-page/Filyos\%20Vadisi\%20Projesi/HTML/index.html\#1

Davidson-Arnott, R. (2010). Introduction to coastal processes and geomorphology. Cambridge University Press. New York.

Duran, A. (2021). Gelik Deresi (Zonguldak) - Bartın Çayı (Bartı) arasının uygulamalı kıyı jeomorfolojisi etüdü (Tez No:666550) [Yüksek Lisans Tezi, İstanbul Üniversitesi]. Yök Tez Merkezi.

Erol, O. (1997). Türkiye'deki kıyı kullanım sorunlarına jeomorfolojik yaklaşım, Ankara Üniversitesi Türkiye Coğrafyası Araştırma ve Uygulama Merkezi, Türkiye Coğrafyası Dergisi, 6, 93-122.

Fan, D., Nguyen, D.V., Su, J., Bui, V.V. \& Tran, D.L. (2019). Coastal morphological changes in the Red River Delta under increasing natural and anthropic stresses. Anthropocene Coasts, 2: 51-71. https://doi.org/10.1139/anc-2018-0022

Filyosvadi (2021, 10 Eylül) Filyos Vadi Projesi. https://www.filyosvadisi.com/

HBB (2006). Filyos (Zonguldak) Kardemir A.Ş. Liman Tesisleri İmar Planı-2006. Zonguldak-Hisarönü (Filyos) Balıkçı Barınağı, Ulaştırma Bakanlığı DLH İnşaatı Genel Müdürlüğü. Zonguldak-Bartın-Karabük (ZBK) Bölgesel Kalkınma Projesi.

Henrico I., Ledwaba, T. \& Zyl, G. (2020). Measuring the effect of wind-driven processes on coastal dunes: a study of the Atlantis and Geelbek dune fields along the West Coast of South Africa. Spatial Information Research, 28, 569-577. https://doi. org/10.1007/s41324-020-00317-x

Himmelstoss, E.A., Henderson, R.E., Kratzmann, M.G., \& Farris A.S. (2018). Digital Shoreline Analysis System (DSAS) Version 5.0 User Guide. https://doi.org/10.3133/ofr20211091

Joesidawati, M.I. (2016). Shoreline change in Tuban district, East Java using geospatial and Digital Shoreline Analysis System (DSAS) techniques. International Journal of Oceans and Oceanography, $10(2), 235-246$.

Kılar, H. \& Çiçek, İ. (2018). Göksu Deltası kıyı çizgisi değişiminin DSAS aracı ile belirlenmesi. Coğrafi Bilimler Dergisi, 16 (1), 89-104. https://dergipark.org.tr/tr/pub/aucbd/article/561264

Kuleli, T., Güneroğlu, A., Karslı, F. \& Dihkan, M. (2011). Automatic detection of shoreline change on coastal Ramsar wetlands of Turkey. Ocean Engineering, 38 (10), 1141-1149. https://doi.org/10.1016/i.oceaneng.2011.05.006

Leatherman, S.P. (2003). Shoreline change mapping and management along the U.S. East Coast. Journal of Coastal Research, 38: 5-13.

Liu, Y., Wang, X., Ling, F., Xu, S. \& Wang, C. (2017). Analysis of coastline extraction from landsat-8 oli imagery. Water, 9(11), 816. https://doi.org/10.3390/w9110816 
Liu, Y., Li, X. \& Hou, X. (2020). Spatiotemporal changes to the river channel and shoreline of the Yellow River Delta during a 40-year period (1976-2017). Journal of Coastal Research, 36(1): 128138. https://www.jstor.org/stable/26864922

Mahamud, U. \& Takewaka, S. (2018). Shoreline change around a river delta on the Cox's Bazar Coast of Bangladesh. Journal of Marine Science and Engineering, 6(3): 80. https://doi.org/10.3390/ imse6030080

McFeters S.K. (1996). The use of the Normalized Difference Water Index (NDWI) in the delineation of open water features. International Journal of Remote Sensing, 17(7): 1425-1432. https://doi. org/10.1080/01431169608948714

Mitra, S.S., Mitra, D. \& Santra, A. (2017). Performance testing of selected automated coastline detection techniques applied on multispectral satellite imageries. International Journal of Earth Sciences, 10: 321-330. https://doi.org/10.1007/s12145-017$\underline{0289-3}$

Morrone, C. \& letto, F. (2021). Shoreline evolution and modern beach sand composition along a coastal stretch of the Tyrrhenian Sea, southern Italy. Journal of Palaeogeography, 10: 7. https:// doi.org/10.1186/s42501-021-00088-y

Moussaid, J., Fora, A.A., Zourarah, B., Maanan, M. \& Maanan, M. (2015). Using automatic computation to analyze the rate of shoreline change on the Kenitra coast, Morocco. Ocean Engineering, 102, 71-77. https://doi.org/10.1016/j.oceaneng.2015.04.044

Norman, T. (1977). Landsat (Erts) görüntüleri yardımıyla bat Karadeniz kıyı akıntllarının incelenmesi. Türkiye Jeoloji Bülteni, 20 (1), 55-62. https://dergipark.org.tr/tr/pub/tib/issue/64643/987516

Ouillon, S. (2018). Why and how do we study sediment transport? Focus on coastal zones and ongoing methods. Water, 10: 390. https://doi.org/10.3390/w10040390

Oyedotun, T.D.T. (2014). Shoreline geometry: DSAS as a tool for Historical Trend Analysis. Geomorphological Techniques, 2,1-12.

Oyedotun, T.D.T. (2016). Shoreline evolution and metocean data behaviour in Southwest England: Is there any historical link? Environmental Processes, 939-960. https://doi.org/10.1007/ s40710-016-0189-4

Özpolat, E., \& Demir, T. (2019). The spatiotemporal shoreline dynamics of a delta under natural and anthropogenic conditions from 1950 to 2018: A dramatic case from the Eastern Mediterranean, Ocean \& Coastal Management, 180. https://doi.org/10.1016/i. ocecoaman.2019.104910

Reed D.J. (2002). Overview: Using geomorphology at the coast, Applied Geomorphology, Part 4: Coast.

Sarwar, M., \& Woodroffe, C.D. (2013). Rates of shoreline change along the coast of Bangladesh. Journal of Coastal Conservation, 17 (3), 515-526. https://doi.org/10.1007/s11852-013-0251-6

Sheik, M., \& Chandrasekar (2011). A shoreline change analysis along the coast between Kanyakumari and Tuticorin, India, using digital shoreline analysis system. Geo-spatial Information Science, 14 (4), 282-293. https://doi.org/10.1007/s11806-011-0551-7

Stanica, A. \& Ungureanu, V.G. (2010). Understanding coastal morphology and sedimentology. Terre et Environnement, 88: 105111.

Thao, N.V., Thanh, T.D., Saito, Y. \& Gouramanis, C. (2013). Monitoring coastline change in the Red River Delta using remotely sensed data. Journal of Marine Science and Technology, 13(2): 151-160. http://www.vjs.ac.vn/index.php/imst
Thinh, N.A. \& Hens, L. (2017). A Digital Shoreline Analysis System (DSAS) applied on mangrove shoreline changes along the Giao Thuy Coastal area (Nam Dinh, Vietnam) during 2005-2014. Vietnam Journal of Earth Sciences, 39(1): 87-96. https://vis.ac.vn/ index.php/ise/article/view/9231

Turoğlu, H. (2005). Tabzon-Sarp arası Karadeniz sahil yolu inşaatının jeomorfolojik etkileri. 29-30 Eylül 2005, i.Ü. Ulusal Coğrafya Kongresi Bildiri Kitabı: 353-362, ISBN 975-6686-02-0.

Turoğlu, H. (2017). Deniz ve göllerde kıyı. İçinde H. Turoğlu, H. \& Yiğitbaşıŏlu, H. (Eds.) Yasal ve Bilimsel Boyutlarıyla KIYI (ss. 0132). Jeomorfoloji Derneği Yayınları, Yayın no: 1, ISBN 978-60567576-0-0, İstanbul.

Turoğlu, H. (2019). Yapay kıyıların jeomorfolojik tanımlaması: Diliskelesi kıyıları örneği (Kocaeli, Türkiye) İstanbul Üniversitesi Coğrafya Dergisi (Istanbul University Journal of Geography), 39: 11-27. https://dergipark.org.tr/tr/download/article-file/804680

Turoğlu, H., Özdemir, H., Gönençgil, B., \& Mater, B. (2004). Hatalı kıyı kullanımının neden olduğu bir problem: Karaburun Limanın (İstanbul) dolması. Türkiye'nin Kıyı ve Deniz Alanları V. Ulusal Konferansı, Adana, Türkiye, 1 - 04 Mayıs 2004, cilt.2, sayfa: 633-642.

UNEP (2006). Marine and coastal ecosystems and human wellbeing: A synthesis report based on the findings of the Millennium Ecosystem Assessment, UNEP. https://digitallibrary.un.org/record/584556

USGS (2021, 10 Eylül). USGS Earth Explorer. https://earthexplorer. usgs.gov/

$\mathrm{Xu}, \mathrm{H}$. (2006). Modification of normalised difference water index (ndwi) to enhance open water features in remotely sensed imagery. International Journal of Remote Sensing, 27(14),30253033. https://doi.org/10.1080/01431160600589179

Wang, K. (2019). Evolution of Yellow River Delta coastline based on Remote Sensing from 1976 to 2014, China. Chinese Geographical Science, 29(2): 181-191. https://doi.org/10.1007/s11769019-1023-5

Wang, X., Zhang, H., Fu, B. \& Shi, A., (2013). Analysis on the coastline change and erosion-accretion evolution of the Pearl River Estuary, China, based on remote-sensing images and nautical charts. Journal of Applied Remote, Sensing, 7 (1). https://doi. org/10.1117/1.JRS.7.073519

Vélez-Castaño, J.D., Betancurth-Montes, G.L. \& Cañón-Barriga, J.E. (2021). Erosion and progradation in the Atrato River delta: A spatiotemporal analysis with Google Earth Engine. Revista Facultad de Ingeniería Universidad de Antioquia, 99: 83-98. https://www.doi.org/10.17533/udea.redin.20200688

Yıldırım, Ş. (2017). Tios-Tieion: söylenecek çok önemli bir şeyi olmayan kent, Trakya Üniversitesi Edebiyat Fakültesi Dergisi, 7, (14), 206-242. https://dergipark.org.tr/tr/pub/trkede/issue/40912/494091

Yıldırım, Ş. (2015). Tios Roma Tiyatrosu. İçinde Atasoy, S. \& Yıldırım, S.. (Eds.) Zonguldak'ta Bir Antik Kent: Tios. 2006-2012 Tios KazIIarının Sonuçları (ss: 271-295), Ankara.

Yüksel F.A. \& Atasoy S., (2007). Karadeniz'de bozulmamış tek yer AntikTios/Tieion'da (Zonguldak-Çaycuma-Filyos) Arkeojeofizik Çalışmaları, 60. Türkiye Jeoloji Kurultayı Bildiri Özleri Kitabı, Ankara, 128-130. 